\title{
Origins of Coeducation in Antebellum Iowa
}

\author{
DORIS MALKMUS
}

IN 1849 Robert and Elizabeth Alexander moved to northeastern Iowa from Indiana, where they had amassed an estimated $\$ 34,000$ by speculating in government land at $\$ 1.25$ an acre and selling it for ten times that amount as immigrants flooded the state. Intending to repeat that performance, Robert, an uneducated "backswoodsman" from Kentucky, described as a "tough old nut" who could outswear and outdrink his neighbors, bought 8,000 acres of land in Fayette County. To attract settlers to their land, Robert and Elizabeth built a private school, called a seminary, in 1855. School lore embroiders this business investment by imputing to Elizabeth the initial impetus for starting the school. As the story goes, when the presiding Methodist elder for northern Iowa encouraged the Alexanders to send their daughters to the Methodist seminary in Mount Vernon, Elizabeth asked, "Why shouldn't we start our own college here?"1

I would like to thank the State Historical Society of Iowa for supporting this project. This research also depended on the maintenance of college archives, for which I am grateful. In particular, I would like to thank Anne Kintner at the Grinnell College Archives, Lynn Helsworth at Iowa Wesleyan Archives, Jill Jack at Cornell College Archives, Harlene Hansen at Coe College Archives, and Natalie Hutchinson of Central College Archives.

1. Few records from the founding period are extant. Most of the history was conveyed in the oral tradition and written down as reminiscences of the founders and other county residents. See George Fitch, Past and Present of Fayette County, lowa, 2 vols. (Indianapolis, IN, 1910), 1:267-68; and M. H. Alderson, "Upper Iowa University," Palimpsest 46 (1965), 129-36. For biographical data on the Alexanders, see Elmore Barce and Ray Jones, "History of Benton County, Indiana," typescript, Upper Iowa University Archives, Fayette, Iowa.

THE ANNALS OF IOWA 58 (Spring 1999). (CThe State Historical Society of Iowa, 1999. 
Fayette County historian George Fitch cited three reasons for the construction of the $\$ 20,000$ school in sparsely settled Fayette County: the district lacked adequate elementary schools and had no secondary education-the seminary would provide both; a seminary would attract settlers and the "best people"; and the rapid escalation in land values as a town grew up around the seminary would abundantly repay the investment. After the seminary opened in January 1857, the Alexanders' ambitions escalated. They determined to elevate their seminary, which taught only primary and secondary subjects, to a college. Because almost every antebellum college in the United States was under the control of a denomination, the Alexanders donated the seminary property to the Methodist church, which reorganized the seminary as college in 1858. The college retained the primary and secondary courses and continued to admit women. Robert Alexander retained a seat on the board of trustees and the right to rename the new college. More interested in inflating the school's prestige than in accurately describing the level of instruction, they gave the new college the grandiose appellation of Upper Iowa University, but true to its local function, it remained coeducational. ${ }^{2}$

The founding of Upper Iowa University is hardly an anomaly in the annals of antebellum higher education in Iowa. Many features of its story-not least its coeducational status-were characteristic of Iowa's other early seminaries and colleges. Yet the apparent simplicity of the story belies the complexity of the forces that intersected during the early settlement of Iowa to

2. Fitch, Fayette County, 267-68, 271. Coeducation was an American word, a term whose meaning ranged from the education of both sexes in the same or coordinate colleges (but not necessarily the same coursework) to the identical education of both sexes together. In this article, coeducation will be used broadly to refer to young women and men studying the same books under the same teachers in the same rooms at the same time whether or not they pursued the same courses or could expect the same vocational or social opportunities. While coeducation has come to refer primarily to higher education, it was first used in 1857 in discussions of union or high schools. Thomas Woody, History of Women's Education in the United States (1929; reprint, New York, 1974), 225. Other standard sources on coeducation include Mabel Newcomer, A Century of Higher Education for American Women (New York, 1959); and Barbara Miller Solomon, In the Company of Educated Women: A History of Educated Women and Higher Education in America (New Haven, CT, 1985). 
allow women access to higher education alongside men. The records of seven of Iowa's antebellum colleges-Cornell in Mount Vernon, Central in Pella, Iowa College (later Grinnell), Iowa Wesleyan in Mount Pleasant, Upper Iowa in Fayette, Western near Shueyville, and the State University of Iowa in Iowa City-suggest at least three sources of coeducation. First, coeducation emerged in seminaries founded by town builders and ministers to attract farmers, merchants, and artisans to their settlements. Second, rural-based religious denominations, especially Methodists, transformed those seminaries into colleges while retaining their practical, scientific seminary curricula and coeducational student bodies. Third, the widespread demand of Iowa settlers for a practical, public education entailed reform of the classical curriculum. Neither the Latin and Greek taught at colleges nor the fine manners and accomplishments of elite female seminaries offered a useful education for ordinary artisans, shopkeepers, teachers, and farmers. Even in the face of the popular demand for practical education, trustees of the new State University of Iowa worried that admitting women would undermine the credibility and prestige of the university. In the end, however, an appointed state board of education decided to retain coeducation at the State University of Iowa, the first state university to admit "both sexes, upon equal terms."

DURING THE SPECULATIVE FOMENT of early settlement in Iowa, land speculators and town builders lent key support to educators and churches in financing and popularizing higher education. Their pragmatic rather than traditional orientation was one of the sources of coeducation. Town builders established seminaries to attract settlers-especially the "best" settlers-as well as to educate their own children. Seminaries depended on the financial support of town builders, whose financial success depended, in turn, on attracting settlers to their town sites. In an era when there were no high schools, seminaries provided virtually the only available secondary education. But the costs and dangers of sending children away for

3. Acts, Resolutions, and Forms adopted by the Iowa State Board of Education at their first session held at Des Moines, December 1858, Act 10, sec. 1. 
high school far exceeded the cost of tuition, so for settlers with children there were significant advantages to moving to a town with a seminary. For both settlers and seminaries, the practical advantages of coeducation were compelling.

Iowa's early settlers were often small-scale land speculators such as Robert and Elizabeth Alexander, who bought tracts of land in anticipation of the price of land rising over time. Because even small-scale investors could reap windfall profits if land they bought at low government prices was sold as town lots, town building became something of a mania in the Midwest. Town builders knew that seminaries were key institutions in creating a sense of permanence and attracting ambitious settlers to otherwise undifferentiated prairie locations. ${ }^{4}$

Land speculators and ministers born in the South played a prominent role in founding seminaries and colleges in Iowa. Besides the Alexanders, North Carolina-born Methodist minister George Bowman initiated the movement for Iowa City College in 1840 and Cornell College in 1852. Ephraim Killpatrick, a South Carolinian, was among the many southerners in Mount Pleasant who persevered in the founding of Iowa Wesleyan; his daughter Lucy became lowa's first female baccalaureate. Ann Eliza Peck Harlan of Kentucky probably encouraged her husband's support of coeducation as president of Iowa Wesleyan. Benjamin Shuey, cofounder of Western College, came from Virginia. And the Baptists who founded Central College were predominantly from Kentucky.

4. R. Carlyle Buley, The Old Northwest: Pioneer Period, 1815-1840, 2 vols. (Bloomington, IN, 1951), 2:116, 147; Stanley Elkins and Eric McKitrick, "A Meaning for Turner's Frontier, Part I: Democracy in the Old Northwest," Political Science Quarterly 64 (1954), 343-44; Paul Gates, "The Role of the Land Speculator in Western Development," Pennsylvania Magazine 66 (1942), 314-33.

5. Memoir of the Reverend George Bryant Bowman (n.p., 1893), copy in the Cornell College Archives, Mount Vernon, IA; Ephraim Killpatrick File and Ann Eliza Peck Harlan File, Iowa Wesleyan College Library, Iowa Wesleyan College, Mount Pleasant, IA; Josephine E. Thostenson, "One Hundred Years of Service, 1853-1953: A History of Central," Central College Bulletin 53 (August 1953), 5; Henry W. Ward, History of Western-Leander-Clark College, 1856-1911 (Dayton, $\mathrm{OH}, 1911), 60$. Some historians have assumed that the founding of colleges in Iowa was due largely to the influx of Yankees into the state after 1852; see Cyrenus Cole, Iowa Through the Years (Iowa City, 1940), 236-40; and Dorothy Schwieder, Iowa: The Middle Land (Ames, 1996), 131. 
College founders as well as town builders counted on exponential increases in the value of land near proposed seminaries and colleges to finance colleges and accrue wealth. The Yale ministers who founded Iowa College in Davenport originally proposed to raise an endowment with the profits on a 24,000 acre parcel in Buchanan County on which they planned to open their college. In 1840 land speculator Anson Cowles envisioned a town on his landholdings at the intersection of the military road and the Cedar River near Mount Vernon. He calculated that the expenses to construct a university, a large park, and a hotel would be covered by the difference between the price he paid for the land and its price when divided into town lots. Amity College in College Springs was part of a land investment association of abolitionists from Galesburg, Illinois. Josiah Grinnell also profited from substantial land speculation. ${ }^{6}$

For families, there were significant advantages to settling in a town with a seminary or college, and town builders did not hesitate to promote them. A circular from Josiah Grinnell to potential emigrants to his colony argued that settling in Grinnell would enable parents to avoid the expense of sending offspring away for their education. Many families did, in fact, relocate to college towns to reduce the costs of educating their children. In 1856 and $1857 \mathrm{~J}$. M. Stone, chair of the faculty of the State University of Iowa, reported to the trustees that several families had moved to Iowa City expressly to defray boarding costs while educating their children. Nelson Fancher, an early Waterloo merchant, moved his family to Mount Vernon to educate his seven daughters and one son. New Yorker Henry Collins explored the unsettled West before choosing Mount Vernon, attracted by the opportunities to educate his children. His daughter Addie received one of the first B.A.s Cornell conferred. Living in the town meant saving boarding coststypically three times the cost of tuition alone-and gave parents

6. Joseph Wall, Grinnell College in the Nineteenth Century: From Salvation to Service (Ames, 1997), 39; A Centennial History of Mount Vernon, Iowa, 1847-1947 (Mount Vernon, 1948), 16; "A Statement of the Commencement, Location, Present Condition, and Future Prospects of Amity College," Circular, Galesburg, IL, 1853, Nodaway Historical Museum, Clarinda, Iowa. 
more oversight during formative years. As more families arrived, the practical-minded town founders benefited.

Town builders often had continuing, direct interests in the operation of local seminaries. After contributing richly to found seminaries, they often became officers of the boards of trustees and continued to assert their interests in seminary affairs. Even at the Baptist Central University in Pella, three of the four officers of the executive board were Dutch settlers. ${ }^{8}$ Most townsmen on the boards of trustees had daughters and sons who attended the seminaries. Ephraim Killpatrick, founding board member of Iowa Wesleyan, had two daughters who entered the freshman college class in 1854. That year three other female freshmen had the same last names as trustees. In 1859 all but one member of Iowa Wesleyan's executive committee shared a last name with a female college student. In the opening year at Cornell, although male students outnumbered females 104 to 57, more females shared a last name with town founders on the board than did males. The daughters of town founders who were also college trustees were among the first baccalaureates west of the Mississippi."

7. Circular of Grinnell College, 1 January 1856, Early College Papers, Grinnell College Archives, Grinnell, IA (hereafter cited as ECP); J. M. Stone, "Report of the Faculty to the Board of Trustees," 6 July 1858, Manuscript Collection, Faculty Reports, University of Iowa Archives, Iowa City; Centennial History of Mount Vernon, 23. Tuition costs ranged from $\$ 15$ to $\$ 18$ per year for the ladies' course at Grinnell (with instrumental music $\$ 30$ per year extra) to $\$ 21$ per year at Iowa Wesleyan. Boarding cost $\$ 1.50$ to $\$ 2.50$ per week at Central, and two to three dollars per week at the State University of Iowa. See catalogs of Iowa Wesleyan University, 1855-56; Central University, 1857-58; lowa College, 1863-64; and the State University of Iowa, 1856-57. Just as the cost of boarding could be a drain on the resources of a family with children attending school in another town, it could boost the resources of a family in a town with a seminary or college.

8. Catalogue of Central University of Iowa, 1857-1858. Rev. Peter Scholte, spiritual and temporal leader of the Dutch migration to Iowa, donated four blocks of town lots and 160 acres of land in his own name. He remained treasurer of the college board of trustees for many years.

9. Catalogs of Iowa Wesleyan University, 1854-55 and 1859-60. One male student and two or three females shared a surname with E. D. Waln, secretary of the board. Jessie Holman and A. I. Willits each shared a name with one male and one female student. These three men were the primary founders of Mount Vernon. Minutes, Board of Trustees of Iowa Conference Seminary [Cornell College], 20 September 1854, Cornell College Archives; Catalogue of Iowa Conference Seminary, 1853-54. 
As these examples suggest, town builders, as well as other local settlers, took a special interest in providing a local education for their daughters. Coeducational schools could attract families containing both sons and daughters-as most did. In some cases, the advantages of living in a community with a school appeared greater for parents seeking to educate their daughters. Some parents, for instance, worried especially about sending daughters any great distance, fearing for their moral and physical safety. College catalogs consistently showed that male students traveled farther than females to attend colleges. At Iowa Wesleyan, for example, 82 percent of male college students were from out of town, compared to only 29 percent of the female students. ${ }^{10}$

For the schools themselves, there were significant advantages to coeducation. Because coeducation meant that trustees had only one building to build and maintain, coeducation was more practical and economical. More significantly, in a highly competitive environment, coeducation substantially enlarged the pool of available students. During the tumult of early settlement, the schools' reputations depended on the number of students and the size of the building. George Magoun, president of Grinnell College, wrote to Professor Leonard Parker that Grinnell's "most formidable competition" was Cornell College in Mount Vernon because of its "381 students of whom 60 are in the College Course." Numbers, then as now, spoke volumes. Magoun added, "They are wise about teaching young ladies." Women increased enrollments in colleges struggling to build facilities, retire debts, and establish a reputation. Coeducation allowed trustees to construct larger and more imposing structures and to boast of large enrollments, providing more "show" for less money. And during the confusion and constant movement of populations during rapid settlement, "show" replaced long-standing reputation as an indicator of quality."

10. Many out-of-town young women apparently had brothers at the same institution. Half of the out-of-town girls at lowa Wesleyan shared a surname with at least one male at the college. Catalogue of Iowa Wesleyan University, 1859-60.

11. G. Magoun to L. Parker, 20 August 1862, ECP. 
MOST OF THESE new coeducational seminaries, however, required the patronage of religious denominations to transform these humble institutions into colleges. If town speculators had not contributed the campus and sometimes the capital to construct the seminary building, few institutions of higher education would have emerged during early settlement. On the other hand, if denominations had not preached on behalf of higher education, enlisted parents and students, supervised instruction, and provided financial support, most of the local seminaries would have become local high schools instead of colleges.

Reforms of higher education in the antebellum period narrowed the differences between seminaries and colleges. Seminaries generally offered a three-year course of practical English and scientific courses roughly corresponding to present-day secondary studies. By 1850, seminaries were usually coeducational, and the better ones offered the same advanced scientific and mathematics courses then taught in colleges. Colleges had slowly added these same scientific courses to their curriculum throughout the nineteenth century, as had female seminaries, whose curriculum paralleled that of coeducational seminaries. A more fundamental distinction was social: colleges saw themselves as educating the future professionals and elites of the country; thus, they excluded women. Seminaries, on the other hand, offered a popular and practical education accessible to the many, including women.

When Iowa seminaries rechartered themselves as colleges, they did so under the aegis of denominational support and control. Religious denominations played the crucial role in mediating between the all-male classical tradition of colleges and the coeducational, practical orientation of seminaries. How they did so varied from denomination to denomination.

Presbyterians, Congregationalists, and Episcopalians remained loyal to the time-honored tradition of classical colleges that emphatically excluded women. Those colleges' four-year course in Latin and Greek had educated ministers and other cultural elites for centuries. Unlike seminaries, which supported themselves through tuition, colleges required external capitalization to pay faculty salaries, build libraries, acquire laboratory equipment, and construct buildings. Few communities during 
early settlement could raise the needed endowments to open a college, so Presbyterians and Congregationalists turned to urban East Coast philanthropists and organized the Society for the Promotion of Collegiate and Theological Education in the West (SPCTEW) to control the distribution of the needed philanthropy to the more conservative of the western colleges. The history of the founding of Iowa (later Grinnell) College is a prime example of the control exerted by East Coast, conservative, college educators over the shape of higher education in the Midwest.

In 1837 a group of theological students at Yale banded together in New Haven to go west as missionary ministers and to "establish upon a firm basis a college for the future state of Iowa." After several years laboring in the field, they felt that the time was ripe to open a college that reproduced the social and intellectual culture of their alma mater. For financial support they turned to the SPCTEW. The SPCTEW, however, already supported two colleges in western Illinois, and it was reluctant to encourage what it saw as needless duplication. The Iowa ministers, stymied in their attempt to find denominational support for their traditional, conservative college curriculum, turned to Davenport landowners and financiers for contributions. Using the paltry support they received from Davenport town builders to open a small preparatory department in that city in 1846, they labored in vain to attract students to their college course. German and southern-born citizens of Davenport violently rejected the anti-alcohol, anti-slavery, and elitist orientation of the college. Under such conditions, it is hardly surprising that the college did not grant its first B.A. until 1854, eight years after it first organized. ${ }^{12}$

12. The Second Report of the Society for the Promotion of Collegiate and Theological Education at the West (New York, 1845), 15; Kenneth Wheeler, "The Institutional and Cultural Development of an American Region: Colleges and Civil Culture in the Old Northwest, 1825-1860" (Ph.D. diss., Ohio State University, forthcoming, 1999); Wall, Grinnell College, 38-41, 50-51; John Scholte Nollen, Grinnell College (Iowa City, 1953), 34 et passim; William Roba, The River and the Prairie: A History of the Quad Cities, 1812-1960 (Quad Cities, 1986), 53. SPCTEW support for Iowa College remained lukewarm; in 1858 the SPCTEW wavered between funding a Presbyterian college at Yellow Spring and supporting the Congregationalist Iowa College in Davenport. Circular, 15 December 1857, ECP. The SPCTEW seldom funded female seminaries and was suspicious of coeducation. In 1843 the SPCTEW sent Joseph Towne and Ansel Eddy to in- 
To cultivate local support and attract students, the trustees of Iowa College determined to relax their admission policies and broaden their curricular offerings. Modifying their original mission of training ministers, they proposed three changes that undermined the Yale college tradition Iowa College was established to reproduce. In 1856 the college introduced a scientific curriculum, allowed students to enroll for partial courses, and admitted nine women who had recently graduated from Davenport High School. ${ }^{13}$

Once they had chosen coeducation-in the face of threats to the college's survival due to meager denominational and local support-the trustees heartily endorsed it. Trustee Rev. Asa Turner wrote, "I should go into it with all my heart. I believe it is the way to do good. It is demanded by the spirit of the age, by the good of the rising generation, and the interests of our great state." Another trustee wrote, "We must go in right away for a Female Department at Iowa College. We can do three times the good with about the same means. ... To my mind the more contact \& intercourse of the honorable kind ... of the two sexes, the better it will be for both \& for the Trustees." ${ }^{\prime \prime}$

Such attitudes reflected a sea-change among Yale-offspring colleges, which traditionally emphasized an elite education following a highly structured, classical curriculum. Now, however, one Iowa College trustee endorsed "throwing every institution ... open to everyone who wished to attend them and was qualified to receive benefit from the same: such as wished to attend part of a course, let them-such as wished to attend the whole

vestigate Knox College for charges of "mingling of the sexes." Richard S. Taylor, "Western Colleges as 'Securities of Intelligence \& Virtue': The Towne-Eddy Report of 1846," The Old Northwest 7 (1981), 41-65. Frederick Rudolph argued that the Yale-based conservatives were among the last bulwarks against the demands for scientific and egalitarian higher education. Frederick Rudolph, Curriculum: A History of the American Undergraduate Course of Study since 1636 (San Francisco, 1977), 56, 112, 75. See also Robert Fletcher, A History of Oberlin College from Its Foundation through the Civil War, 2 vols. (Oberlin, OH, 1943), 1:434-37.

13. Turner to George Magoun, 26 December 1856, ECP; Circular of Grinnell University, 1 January 1856, Grinnell College Archives; Wall, Grinnell College, 68-70, 82.

14. Turner to George Magoun, 26 December 1856, ECP; A. B. Robbins, quoted in Wall, Grinnell College, 111. See also Magoun to Chs. Hendrick, 25 February 1857, ECP; A. B. Robbins to Magoun, 24 December 1856, ECP. 
let them-and those who are worthy [of] the honors of the college give them the honors. ${ }^{\prime \prime}$

Iowa College's proposed changes could not reverse its reputation or its fortunes in the river town, in part because its reforms were half-hearted and patronizing. The college largely retained its classical curriculum, adding only subordinate scientific classes. And women students were admitted only to the recitations and lectures; they could not participate in other student assemblies. Reform activities at the college continued to arouse the animosity of local residents, and in 1858 trustees voted to transfer the college charter, its library, and apparatus to the more congenial Congregationalist colony Josiah Grinnell had founded one hundred miles to the West. At the time of the move, 16 of the 82 students at the Davenport college were women. ${ }^{16}$

Excluded from men's colleges, Presbyterian and Congregationalist female educators created and refined a separate higher education for women that substituted French for classical languages and emphasized composition, sciences, and mathematics while devoting considerable attention to the polite arts. Throughout the antebellum period, the number of courses in needlework declined as the rigor of science and math courses increased. While some female seminaries remained bastions of wealth and prestige, others, such as Mary Lyon's Mount Holyoke Female Seminary, taught a rigorous and pious curriculum to daughters of poor hill farmers.

When Josiah Grinnell had publicized his colony in an 1856 circular to prospective settlers, he announced his intention to open a separate, female seminary modeled after Mount Holyoke. Grinnell's trustees did construct a female seminary with a separate, three-year "ladies' course" on the opposite end of town from the men's college. In 1862 President Magoun requested

15. Circular, 1 January 1856, Grinnell College Archives; Nollen, Grinnell College, $51-58,60$.

16. Turner to Magoun, 26 December 1856, ECP; Wall, Grinnell College, 112.

17. Woody, History of Women's Education, 1:329-457. The best sociological interpretation of women's antebellum education is Kathryn Kish Sklar, Catharine Beecher: A Study in Domesticity (New Haven, CT, 1973). Solomon, In the Company of Educated Women, provides the most thorough history of American women's higher education. 
funding from the SPCTEW to underwrite costs for the college and a planned separate female department, but the SPCTEW crossed funding for the female department off the proposal, demonstrating its persistent funneling of denominational resources to men's colleges while ignoring women's higher education. ${ }^{18}$

The SPCTEW's policy reflected the strong cultural preferences of conservative and moderate New England Congregationalists for ministerial education at classical colleges and separate three-year seminaries for women. Yale-educated evangelical minister Lyman Beecher condemned coeducation. "This Amalgamation of sexes won't do," he argued. "If you live in a Powder House you blow up once in a while. ${ }^{\prime \prime 19}$ His family apparently agreed. His son George was a trustee of Zanesville Female Seminary, and another son, Edward, was president of all-male Illinois College. Although many Congregational and Presbyterian ministers favored and taught at separate women's institutions, most of the resources of those denominations were directed toward men's colleges.

Separate female seminaries, like coeducational seminaries, often supported themselves through fees and tuition, but New England women also formed voluntary associations to help underwrite women's higher education in the Midwest. The Woman's Educational Association of New York and New England sent Catharine Beecher, one of the foremost proponents of women's higher education in the antebellum United States, to the Midwest in 1853 to test the waters regarding the establishment of female seminaries in Quincy, Dubuque, Rockford, or Milwaukee. Beecher convinced Dubuque citizens to finance and construct an elegant female seminary, apparently pledging $\$ 20,000$ from eastern contributors toward an endowment. When the school opened in 1857 with only 80 students enrolled in a building constructed to accommodate 200, Beecher did not follow through with her pledge. The building was soon sold, and the Women's Educational Association channeled its funds to other institutions. ${ }^{20}$

18. Circular, 1 January 1856, Grinnell College Archives; Wall, Grinnell College, 121-23.

19. Quoted in Fletcher, History of Oberlin College, 377.

20. Clarence Aurner, History of Education in Iowa, 5 vols. (Iowa City, 1915), 3:50-

52, 56, 57-61; Robert Belding, "The Dubuque Female Seminary," Palimpsest 63 
Clarence Aurner, historian of education in Iowa, noted that the Dubuque Female Seminary, with its curriculum of classical languages, vocal and instrumental music, drawing, painting, and several of the natural sciences, "was not meant to provide a popular school for the many, but rather ... . [for] the young women of the more prosperous families." Other elite private female schools in Iowa also failed soon after opening. The Mount Ida Female Seminary opened in 1855 and closed four years later, mired in debt. The Lyons Female College opened in 1859 and struggled to maintain a student body before withering in the 1860 s. Genteel female seminaries could not find sufficient students able and willing to pay for the polite education they advertised. Like Iowa College, they found little support in Iowa for their elite institutions. ${ }^{21}$

METHODISTS, Baptists, Disciples, Friends, United Brethren, Christians, Universalists, and other popular American denominations that proliferated on the frontier in the first half of the nineteenth century did not share the Congregationalists' and Presbyterians' rejection of coeducation. Instead, coeduca-

(1982), 34-41. Catharine Beecher promoted and established high quality female seminaries aiming at parity with men's colleges. She hoped those seminaries would train female teachers to be educational counterparts to ministers and missionaries, helping to replicate traditional New England social hierarchies in the West. After publishing her Plea for the West and her Essay on the Education of Female Teachers (both published in 1835), Beecher stimulated the organization of the National Board of Popular Education in 1847 to send teachers west. Sklar, Catharine Beecher, 113, 117, 183, 218-20. Moderate evangelicals like the Beecher family concentrated on the Catholic threat. By 1850 Catholics almost equaled the number of Presbyterians and Congregationalists combined. It is no coincidence that Catharine Beecher helped establish a female seminary in Dubuque, where the Sisters of Charity had opened St. Mary's Academy in 1843, and in Milwaukee with its large German Catholic population.

21. Aurner, History of Education, 3:51-52. Many of the more prosperous Dubuque families, descendants of French fur-trading métis, sent their daughters to the Catholic St. Joseph's Female Academy established just outside of the river town by the Sisters of the Blessed Virgin Mary. St. Joseph's succeeded because of the dedication of the lay Irish sisters and financial support of worldwide Catholics. The Sisters of the Blessed Virgin Mary also taught local Irish children in separate charity schools, a mission that few Protestant seminaries undertook. See "Student Ledger, 1843," Sisters of Charity of the Blessed Virgin Mary, Mount Carmel Archives, Dubuque, Iowa. 
tion became a part of their efforts to reform the classical tradition of higher education to suit the needs of their largely rural membership.

In their formative years, these denominations gave scant support to higher education in any form. Skeptical of the theological preoccupations of college-educated ministers, their members preferred to hear the Christian message through more humble servants. Henry Ward, historian of Western-LeanderCoe College, characterized members of the United Brethren as "hard-headed, rural folk" who "feared that education would beget pride." In Illinois, one group of anti-college Baptists, called Hard-Shells, opposed any higher education, fought the organization of Baptist colleges, and carried enough political clout in Illinois during the 1820 s and early 1830 s to prevent the incorporation of colleges of any denomination before $1833 .^{22}$

During the 1850s, however, these denominations played a crucial role in the spread of higher education in the Midwest. The same religious competition that had led to a splintering of American Protestantism into myriad sects and denominations also led to the proliferation of denominationally sponsored seminaries and colleges in the Midwest. As the new denominations spread and increased their status, they saw the establishment of seminaries and colleges as a way to extend their influence on public as well as private morality and to acquire respect from the more established denominations. The Methodists, for example, with only 22,690 church members in Iowa in 1855, expanded three Iowa coeducational seminaries into colleges between 1855 and 1858: Cornell, Iowa Wesleyan, and Upper Iowa. ${ }^{23}$

22. Donald Tewksbury, The Founding of American Colleges and Universities Before the Civil War (1932; reprint, New York, 1965), 90; Ward, History of WesternLeander-Clark College, 14, 25-26; J. Peck, "Historical Sketches of the Baptist Denomination in Indiana, Illinois, and Missouri," Baptist Memorial and Monthly Chronicle, 15 July 1842, 197-210; Myron Fogde, "Primitivism and Paternalism: Early Denominational Approaches in Western Illinois," Western Illinois Regional Studies 3 (1980), 109-12.

23. Methodists had had a mixed relationship with colleges. When the first Methodist college burned not once but twice almost immediately after opening, the first American Methodist bishop, Francis Asbury, concluded that God did not intend Methodists to build colleges. Instead, he proposed that Methodists should open seminaries for the "many," rather than classical colleges for 
Inter- and intra-denominational competition between rival towns for support for their local college could become destructive in its intensity. By 1843, Mount Pleasant Methodists had already made four unsuccessful attempts to incorporate collegiate institutes. They faced stiff competition from the Methodists in Iowa City, where competing factions had founded two separate institutions, Iowa City College and Snethen Seminary. Not surprisingly, both schools failed, along with the local, coeducational Mechanics Academy, started by a fraternal association of craftsmen working on the state capitol building. Thus, Iowa City was without any secondary education from 1848 until 1855, when the State University of Iowa opened. In this fiercely competitive local and denominational context, women gained admission to colleges on almost equal terms with men with very little opposition. ${ }^{24}$

Methodists in Iowa also found it relatively easy to accept coeducation because the Methodists associated with Iowa colleges were familiar with coeducational seminaries. Cornell College faculty Samuel and Stephen Fellows and David Wheeler, for example, were educated at the coeducational Rock River Seminary in Illinois, whose principal, in turn, had been affiliated with the coeducational Genesee Wesleyan Seminary (later college) in western New York. ${ }^{25}$ When Cornell drew up articles of incorpo-

the "few." The Annual Conference of 1820 recommended that each conference support a seminary, although, significantly, it did not exclude support of colleges. In that spirit, hill-country Yankee Methodists opened large, coeducational seminaries - the first in New Hampshire in 1817, then in Cazenovia, New York, in 1825, and ultimately in each of their conferences in each state. The first Methodist seminaries had separate male and female departments, but men and women had the same teachers, studied the same curriculum, and recited together. William W. Sweet, Indiana Asbury-DePauw University, 18371937 (New York, 1937), 21-24. Eventually, to compete with the Presbyterians for respectability, the Methodists did establish all-male colleges as well. In Iowa, however, Methodist colleges had strong ties to the New York seminary/college tradition through its faculty and teachers.

24. Captain F. M. Irish, "History of Johnson County, Iowa," Annals of lowa 6 (1868), 201, 202-3; Jacob A. Swisher, "The Cradle of the University," Palimpsest 28 (1947), 129-43; Memoir of the Reverend George Bryant Bowman.

25. Nancy Beadie, "From Academy to University in New York State: The Genesee Institutions and the Importance of Capital to the Success of an Idea, 18481871," History of Higher Education Annual 14 (1994), 13-38. A graduate of Cazenovia Seminary, Catherine Fortner, was the first preceptress at Iowa Confer- 
ration as a college, Samuel Fellows wrote article five, which read, "Trustees May Admit Ladies to the same Course of Studies as gentlemen and graduate them with the same honors provided that if they deem it best a separate course of Study may be instituted for females and diplomas granted them in accordance therewith." Fellows subsequently became president of Cornell, which never instituted a separate female course of study. Instead, it followed the pattern of rural, coeducational seminaries where men and women studied side by side. ${ }^{26}$

The Methodist system for supporting schools made them dependent on and responsive to local needs. Unlike the Congregationalists and Presbyterians who funded western colleges with eastern contributions, the Methodist General Conference turned the financial responsibility for higher education over to the district conferences. To promote seminaries, district conferences often required ministers to preach on behalf of conference schools once a year and appointed ministers to act as agents in promoting these institutions among widely scattered church members. The agents rode from house to house and "sold" education to farmers and tradespeople, many of whom had never before considered college education to be important. Ministers and agents encouraged women to enroll in the seminaries. (Rev. Brunson's attempt to convince the Alexanders to send their daughters to Cornell almost certainly was part of the effort to support the conference college.) As various towns built seminaries, their agents criss-crossed the state competing for students. Their activities promoted and popularized higher education

ence Seminary in Mount Vernon. Miss Fortner came to Cedar County under Catharine Beecher's National Board of Education, which sent young women to the West to teach district schools. Miss Fortner's skill as a teacher drew her to the attention of George Bowman, who hired her to teach at Cornell. Memoir of the Reverend George Bryant Bowman; Kable Brothers, Mount Morris Past and Present (Mount Morris, IL, 1900), 86-87.

26. Samuel Fellows File, Manuscript Department, Illinois State Historical Society Library, Springfield, IL; Minutes, Board of Trustees of Cornell College, 20 March 1855. Cornell's support for the admission of women did not extend to women of color. When an African American woman applied for admission to the college in 1859, the trustees, noting the recently opened Methodist coeducational college for freemen and freewomen in Xenia, Ohio, argued that "it would be InExpedient to admit Such persons." Minutes, Board of Trustees of Cornell College, 12 July 1859. 
among a broader constituency of white Protestants, including women, than had ever before attended college. ${ }^{27}$

The Methodists, as the largest Protestant denomination in the United States, reflected the educational views of the mainstream, but members and clergy of the smaller denominations articulated most forcefully the rejection of the classical and genteel traditions. The antebellum period saw the creation of innumerable independent denominations that found adherents among the rural poor. With their small numbers of adherents and antiintellectual traditions, many small denominations did not establish colleges at first. By the 1840s in Ohio and the 1850s in Illinois and Wisconsin, however, these denominations had joined forces with local town boosters to found their own colleges. ${ }^{28}$ When they did, the colleges were usually coeducational, in part because their religious beliefs emphasized spiritual equality, but also because they seldom could afford to support more than one regional institution and did not have enough young men to fill a college. In addition, the smaller denominations feared losing

27. James Finlay, "Agency, Denominations, and the Western Colleges, 1830-1860: Some Connections between Evangelicalism and American Higher Education," Church History 50 (1981), 64-80; Sweet, Indiana Asbury-DePauw University, 22. Some fund-raising strategies could create long-term problems. Almost every antebellum college suffered from the effects of selling "perpetual scholarships," which entitled holders to send each of their children to a college consecutively, without paying tuition, or to "rent" the scholarship to other families to recoup the investment. In $1856 \mathrm{Mrs}$. Benjamin Ford of Mount Vernon tried to persuade her parents and sisters in New York that "if you will sell and come here, you can buy a scholarship for $\$ 60.00$ and send one of the children at a time as long as this institution lasts-and each one of the family can receive a good education." Centennial History of Mount Vernon, 43.

28. Successful coeducational colleges founded by smaller denominations in the Midwest include Alfred College (Seventh-Day Baptist), Hillsdale College (Free-Will Baptist), Hiram College and Eureka College (Disciples of Christ), Heidelberg College (German Reformed), Plainsfield (later North Central) College (Evangelical Association [German]), Illinois Institute (later Wheaton College, Wesleyan Methodist), Muskingum College (Covenanter Presbyterian), Otterbein College and Western College (United Brethren), Urbana College (Swedenborgian), Antioch College (Christian), Lombard University (Universalist), and Lincoln University (Cumberland Presbyterian). All of these coeducational colleges were cooperative ventures between town boosters or land speculators and marginal denominations. Tewksbury, Founding of American Colleges and Universities, 131-32. See also Doris Malkmus, "Small Towns, Small Sects, and Coeducation," paper presented at the History of Education Conference, Chicago, 1998. 
their "brightest youth" to conversion while at a college of another denomination. Since many students found spouses while at college, educating sons or daughters at the college of another denomination meant risking that their children would marry outside the faith.

Members of many of the smaller denominations were, like the Baptist Hard Shells, alienated from the elitism of traditional colleges. They felt excluded from the advantages of a college education and then looked down upon for their ignorance. College founders among the smaller denominations championed reform of the college curriculum and coeducation, reversing anticollege sentiments among their members with painstaking care. They modified higher education to suit the values and means of ordinary farmers and artisans and often argued that educating men and women together was as natural as raising sons and daughters in the same family. Founders of the Seventh-Day Baptist Alfred University in New York called coeducation "the most natural way in the world." This rhetorical strategy implied that the separation of men and women in institutions of higher education was as "unnatural" as the fancy manners and exotic fashions touted at female boarding schools. ${ }^{2 y}$

Rev. Solomon Weaver, a United Brethren minister who had been active in the founding of the Brethren's first college, Otterbein University in Ohio, came to Iowa in 1855 to urge church members here to establish their own college. Having secured the donation of a large tract of land south of Cedar Rapids, he proceeded with plans to construct the college. In the Western College Advocate, a magazine Weaver started to publicize the Brethren's efforts, he spoke to the "hard-headed, rural folk" in their own language. The Brethren were primarily cash poor, ordinary farmers with little or no tradition of college education in their families. They aspired to the advantages of a college education while rejecting the Latin "clap-trap" and class dominance that a college education traditionally involved. Weaver agreed

29. Drawing on research at Alfred University and the conclusions of rural historians, Susan Strong makes a persuasive argument linking coeducation with rural heterosociability. Susan Strong, "The Most Natural Way in the World': Coeducation at Nineteenth-Century Alfred University" (Ph.D. diss, University of Rochester, 1995). 
that colleges and "fancy boarding schools" were sources of pride and immorality and then argued that Brethren needed to create their own version of higher education, one that offered a practical and scientific curriculum in a moral environment. He asked, "How can the mind, besotted by ignorance, ruined by mental vacancy . . . think, reason, resolve, and receive the lofty and sublime doctrines of christianity? ${ }^{\prime \prime 30}$

Weaver's criticisms of the classical curriculum were intense. He criticized the "Latin and Greek jabbering dandies," and the gentility of "fancy boarding schools." He rejoiced that at Western, they were "not annoyed here by a set of dried-up, pharisaical professors of religion" and argued that "life is too short to be spent in gathering up the fabled literature of the ancients." By rejecting the classical men's and ornamental women's curriculum, the Brethren left room for a "course of instruction ... adapted to practical utility" for both genders. They believed that men and women should learn to think independently and observe closely, the hallmarks of the scientific method. ${ }^{31}$

The Brethren instituted a manual labor program at Western so that "work will be made honorable and many noble young ladies and gentlemen ... will be afforded the privilege of a liberal education." At other midwestern female boarding schools, attempts to force all students to perform a minimal amount of domestic labor resulted in no end of controversy. Western College founders were aware that most manual labor programs in other colleges had failed to provide students with an adequate

30. Western College Advocate (Shueyville, IA), July and August 1856. The Brethren agreed to locate the college several miles from Shueyville even though Shueyville itself was a town in name only and was not near any river or major road. Their decision was even more surprising given that Cornell was only 18 miles northeast, the State University of Iowa at Iowa City 16 miles south, and Cedar Rapids Institute, 7 miles north, had just received a large donation from New York farmer Daniel Coe (on the condition that it admit women as well as men). Western College prospered briefly, but when the railroad bypassed Western and Catholic Bohemians settled the area without sending their children to this Protestant, English-speaking college, Western changed its name to Leander College and moved to Toledo in 1880. Erik Eriksson, Cedar Rapids Collegiate Institute and Its Founders, 1853-1866 (Cedar Rapids, 1928), 15-16; Ward, History of Western-Leander-Clark College, 23-25.

31. Western College Advocate, July, August, September, and December 1856 and February and March 1857. 
income, but they insisted on implementing a manual labor system to underscore their commitment to the laboring poor. They went much farther than other antebellum colleges, ruling that "All connected with the College must work." College trustees, "hard-headed" as they were, made their requirement even more emphatic by declaring that "No Professor or Teacher will be employed ... who is unwilling to work." Even more emphatically, they insisted that women as well as men labor out of doors in horticultural production. Just before the college opened, Weaver wrote, "We say to the farmer mechanic and merchantsend on your sons and daughters. ${ }^{\prime 32}$

College founders among the rural denominations articulated reasons for a higher education that rested on rural values and experience. Rural men's and women's roles blurred together as both men and women labored for self-sufficiency and ready cash. Rural women and men acted as deputies for each other during absence or illness. Women could plow, men could care for babies-and given the frequent bouts of malaria during early settlement, they often did. Coeducation reflected the rural social patterns that prevailed during early settlement, patterns that contrasted with the polarization of men's and women's roles in the urban ideal.

THE FOUNDERS of coeducational colleges used their articulation of rural gender values to reinforce their demands for reform of the classical college curriculum. Western College founders, like other small denominations with rural congregations, championed an alternate educational system based on utility rather than the scholastic tradition. They combined demands for a practical education with a rural ideal of a woman as capable, efficient, and intelligent. They championed that ideal to defend the daughters of artisans and farmers from the perceived conceits and advantages of wealthy town girls.

In the Western College Advocate, Solomon Weaver's characterization of an ideal, educated, rural woman contrasted dramatically with an "accomplished young lady." Weaver described an ideal woman as a productive worker, trained to reason inde-

32. Western College Advocate, August 1857. 
pendently, educated to value economy and efficiency rather than ornament or display. Women's roles still included inculcating moral virtue within the family, but this role was tied to practical production rather than moral suasion or sentimentalism. In their manual labor programs, men and women both worked in the college nursery business, unlike most female seminaries that assigned students to domestic, housekeeping duties. The Advocate praised women such as Mrs. Asa Bonney of Maine, who at age 63 with her 73-year-old husband, cultivated and harvested 71 bushels of wheat and 30 bushels of corn by the labor of their own hands. This encomium urged pride in health, labor, and productivity, the opposite characteristics of the sentimental woman-pale, fainting, and occupied with impractical accomplishments. The ideal rural woman was healthy, useful, thrifty, and intelligent. ${ }^{33}$

The value that midwestern coeducational college founders placed on women's industry, intelligence, effectiveness, and self-sufficiency paralleled a national shift away from delicacy and sensitivity in the fashionable female of the 1850s. This sentimental ideal began to be replaced by a notion that "Real Women" were full-blooded, capable, practical, and rational. Coeducational colleges drew upon, articulated, and institutionalized the values of the "Real Woman" as part of their reforms of higher education. ${ }^{34}$

Colonial women's education had been associated with elite society and polite accomplishments. A few expensive female seminaries followed that tradition throughout the nineteenth century. But few rural Iowa women pursued such accomplishments before the Civil War. Refinement and fine arts were hardly compatible with the conditions of early settlement. Instead, most coeducational colleges. offered and most women pursued the practical, scientific courses that led to rural teaching jobs. These "practical" students mixed with the daughters of

33. Western College Advocate, July, October, November, and December 1856.

34. Frances B. Cogan, All-American Girl: The Ideal of Real Womanhood in MidNineteenth-Century America (Athens, GA, 1989); Lori Ginzberg, "'Moral Suasion is Moral Balderdash': Women, Politics and Social Activism in the 1850s," Journal of American History 73 (1986), 601-22. 
the well-to-do, challenging, but not eliminating, the century-old association of higher education with elite manners and morals.

Female gentility remained a persistent, if challenged, female ideal throughout the nineteenth century. For example, in the 1850s the expensive, four-year Oxford Female College in Ohio had nine teachers of music, painting, and needlework and eight teachers for all of the other subjects. ${ }^{35}$ Seminaries that offered these accomplishments cultivated extensive grounds, hired uniformed servants, and charged high tuitions. Descriptions of the Mount Ida Female College of Davenport illustrate the affluent, urban genteel version of womanhood.

The "Ladies College" ... is now being fitted up in the most approved style of Eastern Colleges. The Boarding Hall, (now neatly finished,) and dormitories, are sufficiently commodious to accommodate one hundred Young Ladies as boarders. The Session Rooms have just been furnished with the nicest styles of Boston furniture, diagonally arranged, and the three commodious parlors have been neatly papered, grained, carpeted, and furnished with new and elegant pianos, \&c., for the accommodation of the Musical and Ornamental Department... The College is situated on a delightful eminence in the eastern part of the city, surrounded by a beautiful grove. ... This combines most charmingly for educational purposes, all the advantages both of country and city location, and in general healthfulness, purity of moral atmosphere, sublimity and beauty of scenery, is not excelled, it is thought, by that of any similar Institution of this nation.

In case readers missed the connotations of wealth and gentility that surrounded this female identity, the writer added that the property, "inclusive of the beautiful plat of four acres of ground upon which it is situated, [is worth] between seventy-five and one hundred thousand dollars." A somewhat later genteel seminary near Davenport, the Lyons Female College, boasted that its campus was valued at thirty thousand dollars. ${ }^{36}$

35. Margaret Nash, "'A Salutary Rivalry': The Growth of Higher Education for Women in Oxford, Ohio, 1855-1867," History of Higher Education Annual 16 (1996), 29, 30 .

36. The description of Mount Ida Female College, probably written by its principal, Rev. M. M. Tooke, is quoted in Franc B. Wilkie, Davenport Past and Present (Davenport, 1858), 294-99. Few students were prepared for the curricula advanced seminaries proposed. Lyons Female College opened in 1859 when 
The "fancy female boarding schools" that Solomon Weaver mocked drew upon genteel versions of women as refined, sensitive, pure, and wealthy enough to "rise above" drudgery or material concerns. Although by the 1850 s, all female seminaries had to include rigorous academic content to achieve first-class status, female seminaries seldom lost a focus on shaping the manners and morals of their students. Even denominations that eschewed finery and gentility embraced ladies' departments because of the strong association between woman's spiritual nature and her moral influence in family, church, and society. To that end, Central, Grinnell, and Upper Iowa University enrolled women in three-year "Ladies' Courses" taught by female principals."

Oberlin's renown for admitting women to the regular college course obscures the reality that the vast majority of Oberlin women students enrolled in a three-year ladies' course taught by the faculty wives. There they received instruction on manners, health, and piety. Several of Iowa's seminary/colleges followed the pattern established at Oberlin. Both the first "Lady Principal" at Grinnell, Sarah Candace Pearse Parker, and the first preceptress at Western, Emily Dillman, had graduated from Oberlin's ladies' course. These courses bowed to traditional expectations of separate courses for women and fears that men and women mingling in classrooms could lead to immorality. ${ }^{36}$

But female educators at Oberlin and other evangelical colleges had done much to undercut expectations that a woman's higher education consisted of manners and ornamental subjects. At rural, evangelical seminaries, such as Oberlin, Mount Holyoke, or any of Iowa's coeducational colleges, the ladies' courses es-

Mount Ida closed, offering a four-year college curriculum including Latin, Greek, and a superior gymnasium, but within five years the course was reduced to two years with students proceeding at their own pace, indicating that no uniformity of study could be maintained. Aurner, History of Education in Iowa, 3:56-61, noted the opening of female seminaries in Anamosa (1858), Fayette (1854), Burlington (1857), Mount Pleasant (1863), and Iowa City (1864).

37. Catalogs of Upper Iowa University, 1858-59; lowa College, 1862-63; and Central University, 1859-60.

38. Parker replicated Oberlin's female curriculum at Grinnell, except that it was a three-year program as opposed to four at Oberlin. Catalogue of Iowa College, 1863-4; Catalogue of the Officers and Students of Oberlin College, 1850-51, 19; Ward, History of Western-Leander-Clark College, 48. 
chewed the connotations of wealth that costly ornamental subjects and accomplished instrumental music implied, finding such subjects out of place in the new settlements. Western offered no music or drawing; Baptist Pella offered none in 1857 and by 1865 offered only vocal and instrumental music. Iowa Wesleyan offered vocal and instrumental music as well as French, drawing, and painting for additional fees. George Bowman, founding spirit of Cornell College and the first chairman of the board of trustees, deferred to the expectation that a female education included music and drawing and purchased a piano and hired a music teacher as early as 1854. In 1857 President Fellows noted that the music department had earned three hundred dollars for the college over two years. Cornell also offered French, German, drawing, painting, ornamental hair work, and wax flowers, although no students enrolled for the latter two. Colleges apparently gained income and status by offering such courses, but at Cornell, for example, only about half of the women enrolled in preparatory classes took any of them, at least in part because they could cost twice as much as the regular tuition and were not covered by scholarships. ${ }^{39}$

Coeducational Iowa colleges and seminaries did, however, draw on another typical, but largely forgotten, aspect of antebellum women's education. Since the 1820s successful female seminaries had persistently increased the level of studies in scientific subjects, history, moral philosophy, English, and modern languages. While female seminaries offered only a smattering of Latin - hardly more than would have qualified men for admission to a classical college-women educators had spent decades improving their scientific and English courses. ${ }^{40}$

39. Catalogs of Cornell College, 1859-60; Iowa Wesleyan University, 1859-60; Central University, 1856-57 and 1864-65; Ward, History of Western-LeanderClark College, 48. At Cornell in 1859-60, instrumental music cost ten dollars per term, with rental of the instrument extra; other fine arts cost three to five dollars per term. Minutes, Board of Trustees of Cornell College, 1 November 1854, 8 July 1857; Stephen Fellows, The Fiftieth Annivesary: Cornell College, 1853-1903 (Chicago, 1905), 94; Catalogs of Cornell College, 1854-1860; Tuition Book, 1859-60, Cornell College Archives.

40. See Kim Tolley, "Science for Ladies, Classics for Gentlemen: A Comparative Analysis of Scientific Subjects in the Curricula of Boys' and Girls' Secondary Schools in the United States, 1794-1850," History of Education Quarterly 36 (1996), 129-53. For the influence of Emma Willard on antebellum women's 
The importance of hard science courses to the antebellum women's curriculum is poorly recognized. Modern sensibilities suggest that science is masculine, but that view was promulgated after the Civil War, when universities linked science to industrialism and bureaucratic power. Eighteenth-century sciences were one of the genteel studies associated with a liberal education. As such, well-read and fashionable women swarmed scientific lectures and avidly read scientific treatises as marks of their membership in the world of letters. In addition, many of the most influential antebellum science textbooks used at coeducational seminaries were written by women. In 1855 the State University of Iowa used science texts by Eunice Cutter and Almira Phelps and two history texts by Emma Willard. When colleges adopted scientific courses, the success of teaching women science at the seminary level had already been demonstrated. ${ }^{41}$

The introduction of scientific and English departments into the previously classical curriculum expedited the entrance of women into coeducational colleges. The "scientific courses" offered by men's colleges were usually compact, three-year programs, taught in English, that resembled the long-established female curriculum although college courses included more applied science. For their first three years, men and women studied very similar subjects whether enrolled in Grinnell or Cornell's classical or scientific courses or in the ladies' courses at Rockford Female Seminary, the Methodist Illinois Conference Seminary, or Grinnell College. All shared equivalent study in algebra, trigonometry, geometry, physiology, botany, chemistry, geology, astronomy, rhetoric, zoology, logic, criticism, and moral sciences. The outstanding differences were that ladies' courses required two to four times more history than the coeducational colleges, but no political economy, no calculus, and only preparatory studies in Latin. Classical courses were one

education, see Anne Firor Scott, "The Ever Widening Circle: The Diffusion of Feminist Values from the Troy Female Seminary, 1822-1872," History of Education Quarterly 19 (1979), 3-25. However, Scott's conclusions are more pertinent to the antebellum South than to the Midwest. See also Alma Lutz, Emma Willard: Daughter of Democracy (New York, 1929), 109-10.

41. First Catalogue of the State University of Iowa, 1855, 10-11. 
year longer and included six to ten terms of Latin and slightly less Greek. ${ }^{42}$

Similarities between the female seminary and scientific courses removed any intellectual basis for excluding women from colleges. The separate education of the two sexes could only be justified on the basis of "women's special nature." That is exactly what happened in the affluent, urban East. It is not what happened in rural coeducational colleges in Iowa.

The most popular college courses for rural men and women were those leading to the science degrees that helped women find jobs as seminary teachers and men farm scientifically or find employment in town. Most women pursued a higher education to prepare themselves vocationally and to advance their opportunities as teachers. All of the Methodist colleges offered special normal classes for those planning to teach in primary schools. In colleges without normal classes, students followed the shorter, scientific course that was best suited to train teachers for higher schools. Teaching, one of the few vocational opportunities for rural women, demanded some post-elementary educationavailable primarily in the preparatory departments of seminarycolleges-but not a degree. This helps explain why the vast majority of early female students stayed for less than a year in preparatory departments. More than half of the 181 female students who passed through the doors of Cornell from 1853 through 1856 attended for one year or less. Between 1859 and 1864, the average Cornell preparatory student attended for 2.13 terms, or approximately two-thirds of one year. After teaching rural schools for a year or more, teachers could return to pursue a B.S. to prepare themselves for more respected and better-paying positions as preceptresses, principals, or teachers of ornamental subjects. ${ }^{13}$

42. College catalogs for Rockford Female Seminary, 1855-56; Illinois Conference Seminary, 1857-58; Cornell College, 1854-55; and Grinnell College, 1862-63.

43. Catalogs of Iowa Wesleyan University, 1858-59; Upper Iowa University, 1860-62; and Cornell College, 1854-1860; and Tuition Book, 1859-60, Cornell College Archives. Of the 82 women students whose names appeared in the tuition book, 18 stayed for only one term, and only 5 students in 1859-60 stayed for three consecutive terms or more. The figures represent my analysis of the catalogs and matriculation books. The students listed in catalogs vary somewhat from those listed in the tuition and matriculation books, reflecting casual attendance. 
The vocational advantages of ornamental studies for women teachers was most clearly, if rather crassly, stated by the principal of the elegant Mount Ida Female Seminary in Davenport. He argued that a daughter's education in piano, drawing, and art was a good investment. An uneducated daughter, thrown upon her own resources, he wrote, "could earn say one hundred dollars a year at ordinary service without an education. But with a thorough education, as an accomplished Instructor, she can earn from three to five hundred dollars a year. ... Now suppose it costs to educate that daughter, ... . say four hundred dollars. We have then an annual income upon the capital actually invested in her education of seventy-five per cent." Young women who planned to make a career of teaching were aware of the difference in pay between district teaching and a position in a seminary-college. If women sought to acquire positions as "accomplished Instructors," which paid almost three times as much as teaching district school, they needed to invest in years of study in music and art or obtain a college degree."

Women who planned to teach in the higher branches had little use for a classical curriculum, but they did need the science and English courses taught in seminaries. A classical college education, with its years of study in Latin and Greek, was too arcane for training rural teachers. At Cornell, where enrollment records from the 1850s have survived, few women pursued the classical course, which could not help them find regular employment. Most women (like men) pursued the more practical, three-year scientific degree. Only three Iowa women earned a B.A. before the Civil War compared to at least ten who earned a B.S. At Wesleyan and Cornell, women constituted almost half of the stu-

44. Quoted in Wilkie, Davenport Past and Present, 297. Teaching was also seen as a means of self-support in case of "blessed singleness," widowhood, or financial reverses. Education also became a form of patrimony for young women. Elihu Springer, Baptist itinerant preacher in Illinois, wrote, "It is my intention to give them all [sons and daughters] a good education and a good trade. As to property, I never expect to give them any of consequence." Elihu Springer to Mary M. Davidson, 21 December 1849, SC 1445, Illinois State Historical Society Library, Springfield, IL. In 1852 Frances Wood earned a good wage of $\$ 44$ for teaching district school in rural New York during the winter term. The following year she earned $\$ 300$ as principal of the Mount Carroll Seminary in Illinois even though preceptress's wages were lower in the West than in New York. 
dents in the scientific courses, but only 12 and 20 percent respectively of bachelor of arts students in 1859-60. ${ }^{45}$

The few women in the classical courses were isolated socially from the men and intellectually from the women pursuing scientific subjects. According to school rules, women were forbidden to socialize with men outside of class. The few women who pursued a classical education were usually the daughters of college faculty or trustees who could look to supportive parents for encouragement and a sense of identity. But even those women could not look beyond a classical course of study to a career that utilized a classical training. Amanda Plaskett, who earned a B.A. at Cornell in 1861, returned to Cornell and taught art after the Civil War. The other women baccalaureates married ministers and their subsequent lives have been lost to history. ${ }^{46}$

The few women who pursued a full college course and graduated with either a B.A. or a B.S. were separated from the bread-and-butter, "two-term" students by years of study and possibly economic status. At Central College, the declared assets of the families of female preparatory students were only one-third $(\$ 2,723)$ of those of college students' families $(\$ 8,422)$. It is reasonable to conclude that the families of preparatory students would have found it more difficult to finance years of study than would the parents of the college students."

At the State University of Iowa, tuition during the 1850s was low, enabling the daughters of farmers and artisans to remain in school for protracted periods alongside the daughters of wellto-do merchants and financiers. In this potentially egalitarian environment, class distinctions remained in place, as daughters of farmers and artisans studied to be teachers while daughters of

45. Catalogs of Cornell College and Iowa Wesleyan University, 1859-60.

46. "The Beginnings," Cornell College Chapbook 18 (1945). A study of the educational careers of Iowa's early women educators is overdue. Cordelia Throop, a graduate of Hamilton Seminary in New York taught the advanced department of the Keokuk public school; Cornell's faculty included Catherine Fortner, who graduated from Cazenovia Seminary, and Harriette Cook and Susan Hale, who graduated from Tilden College in New Hampshire; Oberlin graduates Sarah Candace Pearse Parker and Emily Dillman, were preceptresses at Grinnell and Western, respectively.

47. Catalogue of Central University, 1859-1860. Of 167 students, 67 were female, and of those 49 were found in the 1860 federal census. 
the town's elite pursued college studies. ${ }^{48}$ Class distinctions that were probably very patent to students become apparent to the historian only with careful decoding of the graduation ceremony. Most antebellum colleges demanded original compositions by their female students on a weekly basis (while men were required to declaim). Male and female students compiled these essays into hand-written literary publications, and women read from theirs at the commencement exercises. At the State University of Iowa in 1857 the young women read from two distinct magazines: the "Ladies Offering" apparently represented the efforts of college students, while the "Gem of Thought" included the work of preparatory/normal students. The fathers of the authors of "Ladies' Offering" included a lawyer, two merchants, a foundry owner, a stage line owner, and a physician, whose real estate was valued at an average of $\$ 31,000$, according to the 1860 federal census. Fathers of the other group of essayists included four farmers, a marble cutter, a stonecutter, a blacksmith, and a physician. Their assets were not given in the 1860 census, but the average reported assets of all students' families was only $\$ 9,115$. All of the daughters of the artisan group attended the normal school rather than college preparatory classes. ${ }^{49}$

In rural Iowa, the first women to graduate from classical courses came from families with relatively high levels of interest in education; they were frequently daughters of trustees or teachers in the college. At Iowa Wesleyan, Lucy Killpatrick, daughter of college founder and local office holder Ephraim

48. In 1855-1859, 61 percent of female students' fathers were farmers and 14 percent were skilled laborers, based on a comparison of State University of Iowa catalogs, 1855-59, with the state and federal censuses for 1856 and 1860 respectively. Social distinctions at the state university are almost invisible to casual inquiry. Enrollment records show only that students enrolled in several departments. Only their length of study would have distinguished scientific and classical students

49. "Order of First Commencement Exercises in Iowa State University, June 30, 1857," Archives of the University of Iowa. For comparative purposes, the assets of families at Iowa Wesleyan were valued at $\$ 14,312$; at Cornell, $\$ 8,613$; at Central, \$5,572; at Grinnell, \$3,793. These figures are only suggestive, however, because too few students or their families could be identified and because higher assets probably relate to the higher price of land in the eastern communities. Figures and fathers' occupations were compiled from the 1856 lowa state census and the 1860 federal census. 
Killpatrick, completed the classical course and received a B.A. in 1859 in a special ceremony to honor her as the first woman to receive a B.A. at the school. At Cornell, Addie Collin and Amanda Plaskett entered the regular classical course in 1857, graduating in 1861. Addie Collin's father was known to his Mount Vernon neighbors as "the squire," while Amanda Plaskett's father was the college steward, a position that may have entitled her to free tuition. Nettie Hart, whose mother had served as "lady principal" of the Iowa City College in 1846, was the first woman to earn a B.A. from the State University of Iowa, in 1863. Her sisters also earned degrees from the State University of Iowa in later years. Daughters of educators and ministers and the occasional town gentry spearheaded women's entry into the classical college courses. Few rural women followed their lead, however, possibly because most chose a more useful education..$^{50}$

THE LINKS between curricular reform and coeducation are particularly evident in the debates over coeducation at the State University of Iowa. By the eve of the Civil War, all of the private colleges in Iowa had united coeducation with a reformed curriculum, but all of them were primarily seminaries or were located in fairly isolated, rural communities-usually both. ${ }^{51}$ Admitting women to the State University of Iowa would publicly sanction women's right to an equal higher education. It was not a step that would be taken lightly by those who were responsible for the university's reputation.

Prompted by the state legislature, trustees opened the State University of Iowa (SUI) in 1854, before a president had been hired or a curriculum determined. Although the federal govern-

50. Edward Ketcham to Louis Haselmayer, 8 March 1974, Ephraim Killpatrick File, Iowa Wesleyan College Archives; Lucy Killpatrick File, ibid.; Catalog of Iowa Wesleyan University, 1860-61; Minutes, Board of Trustees of Cornell College, 27 June 1861, 25 June 1862; Ruth Gallaher, "The Methodist Episcopal Church of Iowa City," Iowa Journal of History and Politics 37 (1939), 403.

51. Iowa Wesleyan at Mount Pleasant and Cornell College at Mount Vernon opened coeducational collegiate departments in 1854; Iowa College in Davenport admitted women in 1856, Western College in 1857, Central College in Pella in 1858, and Upper Iowa University in Fayette in 1861. 
ment had set aside more than 46,000 acres of land to fund Iowa's university in 1848, minor entanglements and political squabbles repeatedly postponed its organization until Governor Grimes and the state legislature prodded university trustees in 1854 into a provisional organization of the university. At that time, curricular reform had broad popular support, amounting to a virtual political mandate. Grimes's inaugural address in 1854 urged the state legislators to fund a state-controlled, "practical scientific or polytechnic school." Sentiments in favor of a statesupported scientific school remained high, but when SUI opened in 1854, there was no president and little more than preparatory classes were offered in the humble Mechanic's Academy building. In 1855 Amos Dean reluctantly accepted the position of president on the condition that he could remain in Albany, New York. Lacking leadership, vision, and an edifice, SUI continued to function as a local seminary. ${ }^{52}$

Without a strong leader to advocate or reject the male-only collegiate tradition, local needs dominated the university, and women studied alongside men. The faculty report of December 1856 claimed 89 students (including 27 women) currently enrolled in the university. Since it had opened, 152 students had enrolled in the preparatory courses and 80 in the teacher training course, with a small, but indeterminable number taking courses in the college departments. The faculty noted that few out-oftown students could afford to attend the university because of the high cost of boarding in Iowa City, but about twenty Iowa City women were in regular attendance. The faculty praised the success of its coeducational arrangements, stating that the women's "individual progress in study compares very favourably" with the men and "their discreet and lady-like deportment" had a "salutary influence upon the whole institution." Contention arose, however, when citizens and trustees from outside of Iowa

52. My understanding of Dean's position at the university follows that of Aurner, History of Education in Iowa, 4:3-23; and Thomas H. Benton, An Address Delivered at the Annual Commencement of the State University of Iowa, 21 June, 1867 (Davenport, 1877), 42-43. Benton's address offers a detailed account of the founding years of the university drawn primarily from the minutes of the Board of Trustees. See also Minutes, Board of Trustees of the State University of Iowa, Record Book A, 1847-1876, University of Iowa Archives, Special Collections, University of Iowa Library, Iowa City. 
City protested spending money set aside for the university on the education of Iowa City high school students. . $^{33}$

When Amos Dean became the new president of the State University of Iowa, he knew the state legislators were more inclined to support a practical rather than a strictly classical curriculum.". Dean was from Albany, New York, where the nearby Union College had instituted a successful scientific college curriculum. Albany was also the home of one of the nation's most successful state normal schools. Dean organized the State University of Iowa into nine semi-independent departments. Completion of two years of course work in three of the nine departments qualified a student for a B.S.; a B.A. required four years of work in six departments. Since ancient languages constituted only one department, this curriculum permitted students to obtain a bachelor of arts degree without the obligatory work in Latin and Greek demanded at most colleges of the time. ${ }^{.5}$

Aware that their reformed plan would face scrutiny by traditional college men, Dean and the trustees needed to establish a credible college curriculum while still satisfying legislators' demands for practical education. Since many educated Iowans associated coeducation with seminary-level rather than collegelevel work, it was perhaps inevitable that coeducation would become an important issue in the debates over the future of SUI.

53. Student registers show that of the 27 women enrolled in 1856, 11 were in the preparatory department, and 7 in the normal department, with 9 unknown. J. M. Stone argued that although it appeared that the State University of Iowa educated primarily the children of the town, that resulted from the number of families from around the state who moved to Iowa City for their children's education. Stone, "Report of the Faculty to the Board of Trustees."

54. In 1858 the state legislature appropriated $\$ 10,000$ to a group of Iowa educational reformers to establish a state college of "practical polytechnics." This polytechnic school at Ames later became the recipient of the Morrill Land Grant. The same year that the legislature passed this funding proposal the trustees of the State University of Iowa voted to suspend university classes for lack of adequate facilities and resources. Aurner, History of Education in Iowa, 4:9; Cole, Iowa Through the Years, 237-39; First Catalog of the State University of Iowa, 185657.

55. First Circular of the State University of Iowa, 1 September 1855, University of Iowa Archives; Minutes, Board of Trustees of the State University of Iowa, Record Book A, 1847-1876, 27 and 28 April and 4 August 1858, ibid.; Iowa Weekly Reporter, 5 and 26 May and 14 July 1858. 
Contention about the admission of women to the State University of Iowa began at the January 1858 board meeting, when university trustee Judge Lincoln Clark from Dubuque moved to exclude women. His motion was defeated by only one vote, but three months later, on April 28, 1858, new board members had rotated into place and Chancellor Amos Dean was in attendance. Judge Clark moved "that it is inconsistent with the design of the University and inexpedient that females should be admitted to the University for instruction therein, except to hear lectures of the professors." This time the motion passed by one vote, along with a motion to close the state university from June 1858 to September 1859 while revenues from university land sales accumulated. In an article in the Iowa Weekly Reporter, Amos Dean outlined his objections to the continuation of the preparatory department at SUI and his intention to reform the curriculum. He did not even mention the exclusion of women, signaling that in his mind, women were associated only with the normal and preparatory departments. His reformed curriculum was designed solely to "fit young men for the different business pursuits of life..$^{1 / 56}$

The closing of the university and reform of the curriculum sparked editorial rage in the Iowa City press. Iowa City trustees on the executive committee of the university board called for a meeting of the full board on August 4, 1858, to reconsider the suspension of classes. The board, chaired by Josiah Grinnell, sustained its previous resolution-the Iowa City trustees voting to keep the university open and those from Cedar, Dubuque, Henry, Lee, Muscatine, and Scott Counties voting to suspend. ${ }^{57}$

56. Benton, Commencement Address, 49-50; Minutes, Board of Trustees of the State University of Iowa, Record Book A, 1847-1876, 6 January and 27 and 28 April 1858, University of Iowa Archives; Robert E. Belding, "Iowa's Brave Model for Women's Education," Annals of lowa 43 (1976), 342-48.

57. First Circular of the State University of Iowa, 1 September 1855; Benton, Commencement Address, 49-51; Minutes, Board of Trustees of the State University of Iowa, Record Book A, 1847-1876, 4 August 1858, University of Iowa Archives. The account of these events in the Iowa Weekly Reporter for May through August 1858 suggests that the "old board" voted to keep girls in while Chancellor Dean was a wild-eyed reformer who convinced the trustees to exclude girls and embark on an untested departmental system. 
However, Iowa City trustees did manage to persuade their colleagues to keep the normal department open and to continue to admit women to it while university classes were suspended. Normal schools provided a less liberal, less genteel, and more vocationally specific preparation for teaching, thus constituting a feminine counterpart to the masculine "practical education." In 1860,57 of the 89 normal students and all 6 of its graduates were women. Despite the president's lack of interest in admitting women to the university, popular opinion demanded that the state support the preparation of teachers, most of whom were women. The next year, the new state constitution gave control of all of Iowa's education to an appointed board of education, which immediately determined that the State University of Iowa would remain open to "the youth of the State, of both sexes, upon equal terms." ${ }^{158}$

While the SUI faculty and many state legislators supported coeducation, others hoped that coeducation was a temporary condition. For trustee Thomas Hart Benton, for example, coeducation was a temporary expedient "until an institution designed exclusively for the education of females is established by the state" for the "cultivation of proper social relations between the sexes." For many farmers and artisans, however, coeducation already represented the "proper social relations between the sexes. ${ }^{\prime 59}$

FAR FROM BEING A TEMPORARY EXPEDIENT, coeducation spread from the colleges of Iowa and the Midwest across the nation in the years after the Civil War. Women of that era who struggled to gain access to higher education succeeded in convincing Americans that they were capable of and should receive a higher education. Coeducation emerged, however, in the antebellum Midwest as a result of conditions of early settlement, rural gender values, and widespread demands for a practical education for ordinary citizens.

58. Acts, Resolutions, and Forms adopted by the Iowa State Board of Education, Des Moines, Iowa, December 1858, Act 10, sec. 1; Benton, Commencement Address, 59.

59. Benton, Commencement Address, 97-98. 
Coeducation was a genuine western innovation reflecting western society and values during early settlement. The isolated locations and reliance upon local contributions for financial support freed rural midwestern colleges from the dominance of urban educational and gender ideals, allowing innovation and reform to create authentic American institutions. When popular demands for a state-supported, scientific university increased in the 1850s, agents for rural-based, denominational colleges had already prepared the soil, linking coeducation with a practical education for the many rather than an elite education for the few.

The emergence of coeducation in Iowa's early seminaries and colleges reflected the informal social patterns of early settlement. However, rural practicality never entirely displaced urban gentility; even the most outspoken, populist colleges in antebellum Iowa offered separate "ladies courses." Coeducation, even with its egalitarian rhetoric, could not eliminate the inequalities based on class, gender, and race that existed in the larger society. Nonetheless, the momentum behind the egalitarian reforms of early settlement raised coeducation far enough above the high water line that later, male-only backlashes failed to wash it away. 